\title{
INFRASTRUCTURES' EFFECT ON ECONOMIC GROWTH IN SOUTHEAST SULAWESI
}

\author{
Manat Rahim \\ arifmanat@gmail.com \\ Armin \\ La Ode Suriadi \\ Muhamad Armawaddin \\ Fakultas Ekonomi dan Bisnis, Universitas Halu Oleo \\ Kambu, Kota Kendari, Sulawesi Tenggara 93561 \\ received: 13/9/18; revised: 18/9/18; published: 29/6/19
}

\begin{abstract}
The aim of the research is to analyze the effect of infrastructures on economic growth in Southeast Sulawesi. The data used the secunder data which formed time series-based. The data was obtained by publication and legal documents of Statistic Center Unit and relevant institution. The method of analysis used ordinary least squares with panel data. Thus, the data analysis of this research was regretion model with panel data. To estimate regretion of panel data, the researcher used common effect,fixed effect and random effect method. The findings of this research showed that insfrastructures comprised road, harbor, water and electicity simultaniously and significantly influenced the economic growth in Southeast Sulawesi. Partially, only harbor and electricity significantly affected on the economic growth Southeast Sulawesi.
\end{abstract}

Keywords: infrastructures; economic growth

\section{INTRODUCTION}

Infrastructure is very big influence on the development or economic growth of a region, where adequate infrastructure will affect the process of acceleration or development of a city or region. As an organization, local governments have local revenue to finance public expenditure. Government expenditures are allocated for the financing of various sectors of community life including the financing of infrastructure development. Logical consequence, government expenditure can influence either directly or indirectly to the growth of regional economy marked by the amount of GRDP. This also raises the critical question, how much influence the government expenditure specifically in the field of infrastructure to PDRB.

The influence of fiscal policy, the composition of government spending on economic growth has been the object of research and deepening by economists since a long time ago. Semler, Willi (2007) who concluded that the increase in economic growth is largely determined by the amount of public spending, among others in terms of infrastructure development such as roads and bridges. The development of infrastructure in the transport, irrigation, agriculture, education, health sectors has the potential to increase economic growth by Ghosh, (2005: 81). Meanwhile, the opinion expressed by $\mathrm{Vu} \mathrm{Le}(2005)$ that public spending is an important instrument for the government to promote economic growth. In addition, public investment is also a factor that contributes to the accumulation of capital. The importance of the infrastructure role, both infrastructure built by the government and by the private sector, in support of development begins with the introduction of the growth model by Rostow. According to Rostow, one of the many economic development strategies is spending to finance adequate infrastructure to accelerate the pace of economic growth. Capital accumulation occurs when a portion of the income is saved and reinvested in order to increase output and income in the future (Todaro, 2007).

With regard to Rostow's growth model, Southeast Sulawesi's economic growth, GDP growth rate continues to increase significantly from year to year, even in 2012 Southeast Sulawesi's economic growth reached 10.41 percent. This can be seen in Figure 1.

Infrastructures are not only needed by household, but also industry, so the improvement of infrastructures will bring the prosperity and the accelaration of economic growth. Region or city with good infrastructures will give bigger benefits in attracting an investor to invest in the region or city. The previous researches from Halu 
Oleo University and World Bank (2012) reported that the adequate infrastructures, such as elictricity, clean water, and santation in poor household in Southeast Sulawesi were still low. Then, the road of the province was still under average of the national calculation. Besides, the roads province performance did not show the good improvement especially the surface of asphalt roads. However, the length ratio of the national roads and regency roads per weidth in Southeast Sulawesi were higher than national . average. While, the harbor infrastructure showed the improvement namely in Harbor of Marhum Bau-Bau, Pomala Kolaka and Kendari.

Based on the empirical and theoretical reviews, the extent to which the influence of road infrastructure, ports, water and electricity on economic development in Southeast Sulawesi is very important to be analyzed and studied more deeply in this research.

Todaro (2007) defined infrastructure as one of the important factors which decides the economic growth. The underlying amount of physical and financial capital embodied in roads, railways, waterways, airways, and other forms of transportation and communication plus water supplies, finacila instituons, electricity, and public services such as health and education. The level of infrastructural development in a country is a crucial factor determing the pace and diversity of economic development.

According to Stiglitz (2000), public goods which are provided by the government are infrastructures, such as road, harbor, water and electricity. The infrastructures here are not pure public goods because road, harbor and electricity have small marginal costs, but not zero.

Munnel (1990) stated that infrastructures such as road, electricity, water, school and hospital created positive externality which leads to the improvement of economic. In other sides, infrastructure is long-term investation which can support the economic growth.

The role of the government in providing the infrastructures can decrease the income discrepancy and long-term effect of Bruto Domestic Product per kapita improvement. In one side, infrastructures development program in each country concluded that the program focused on the basic need and human conectivty namely water, electricity, energy, and transportation (roads, train, harbor, and airport). Weil (2009) stated that disparity of infrastructures availability and human capital will influence the economic growth of the country. Wu (1998) said that disparity degree among regions in China was different from Coastal region, central and western. While, Demurger (2001) used 24 provinces in china as data collection and concluded that infrastructures condition significantly influenced toward the disparity of regional development. Calderon (2011) stated that economic growth had positive relationship and significantly affected on the stock and the quality of the infrastructures in the region or city.

In Indonesian, the previous researches on infrastructures toward economic growth namely conducted by Sibrani (2002), Yanuar (2006), Prasetyo (2008), and Prasetyo and Firdaus (2009). The first, Sibarani (2002) found that infrastructures (electricity and education) positively and significantly influenced on income per capita of Indonesians, while road and telephone were not significant. The policy of infrastructures development centered in Java and East Indonesia. The second, Yanuar (2006) which used panel data in 26 provinces showed that physics capital, road infrastructures, telephone, health, and education gave the positive impact on economic output. The third, Prasetyo (2008) inferred that electricity, length of the road, modal stock, and region otority positively affected on economic growth in west Indonesia, while water did not give the positive effect. The fourth, Prasetyo and Firdaus (2009) found that the economic growth of Indonesia was influenced by the availability of infrastructures, such as electricity, roads (asphalt), and clean water.

\section{METHODS}

The method of analysis was ordinary least squareswith panel data. Gujarati (2010) and Agus Widarjono (2013) stated that in estimating the regretion of panel data, there were three techniques namely common effect, fixed effect and random effect. For more details, it can be seen below:

Common Effect(CE).

$$
\mathrm{Y}_{\mathrm{it}}=\beta_{1}+\beta_{2} \mathrm{X}_{2 \mathrm{t}}+\cdots+\beta_{\mathrm{n}} \mathrm{X}_{\mathrm{it}}+\mu_{\mathrm{it}}
$$

Fixed effect(FE).

$$
Y_{i t}=\alpha_{1}+\alpha_{2} D_{2}+\cdots+\alpha_{n} D_{n}+\beta_{2} X_{2 t}+\beta_{n} X_{i t}+\mu_{i t} \cdots \cdots
$$

Random effect(RE).

$$
\mathrm{Y}_{\mathrm{it}}=\beta_{1}+\beta_{2} \mathrm{X}_{2 \mathrm{t}}+\cdots+\beta_{\mathrm{n}} \mathrm{X}_{\mathrm{it}}+\varepsilon_{\mathrm{it}}+\mu_{\mathrm{it}}
$$

There are three tests which used to decide the appropriate technique to estimate the regretion of panel data as follows. F statistical test is used to decide whether common effect or fixed effect model. Langrange Multipler (LM) testis used to decide wheteher common effect or random effect model. Hausman test is used to decide whetherfixed effect or random effect.

Langrange Multipler (LM) is used to decide wheteher common effect or random effect model. Significance test of Langrange Multiper (LM) is developed by Breusch-Pagan. Metode Breusch Pagan to test the significance of random effect model which is based on the residu value of common effect model. The formulation of LM as follows. 


$$
\begin{aligned}
L M & =\frac{n T}{2(T-1)}\left(\frac{\sum_{i=1}^{n}\left(\sum_{i=1}^{T} e_{i t}\right)^{2}}{\sum_{i=1}^{n}\left(\sum_{i=1}^{T} e_{i t}{ }^{2}\right)}-1\right) \\
& =\frac{\mathrm{nT}}{2(\mathrm{~T}-1)}\left(\frac{\sum_{\mathrm{i}=1}^{\mathrm{n}} \mathrm{Te}_{\mathrm{it}}}{\sum_{\mathrm{i}=1}^{\mathrm{n}}\left(\sum_{\mathrm{i}=1}^{\mathrm{T}} \mathrm{e}_{\mathrm{it}}{ }^{2}\right)}-1\right) \ldots \ldots \ldots \ldots \ldots . .
\end{aligned}
$$

LM test is based on the distribution of chi-squares with the degree of freedom as the number of independent variable. If the score of LM is higher than the score of chi-square critics, the null hypothesis is rejected. It means that the the suitable estimation for the regretion of panel data is random effect than common effect model. In contrast, If the score of LM is lower than the score of chi-square critics, the null hypothesis is accepted. It means that the the suitable estimation for the regretion of panel data is common effect model.

Hausman test is used to decide whetherfixed effect or random effect. Hausman test is based on the consistence of both methods of OLS and GLS, but OLS is not efficient in null hypothesis. In other sides, alternative hypothesis of OLS is consistent, but GLS is not consistent. Thus, its null hypothesis test for the the estimation result is not different, so Hausman test can be done based on the estimation difference. Hauman test can be explained by using matrix covarian for vector difference $[\beta \mathrm{OLS}-\beta \mathrm{GLS}]$ :

$\operatorname{var}\left[\beta_{O L S}-\beta_{G L S}\right]=\operatorname{var}\left(\beta_{O L S}\right)+\operatorname{var}\left(\beta_{G L S}\right)-\operatorname{cov}\left(\beta_{O L S} \beta_{G L S}\right)$ $-\operatorname{cov}\left(\beta_{O L S} \beta_{G L S}\right)$.

Because the difference of covariance from effecient estimator and not efficient estimator is zero, so:

$$
\operatorname{cov}\left[\beta_{O L S} \beta_{G L S}, \beta_{G L S}\right]=\operatorname{cov}\left(\beta_{O L S} \beta_{G L S}\right)-\operatorname{var}\left(\beta_{G L S}\right)=0
$$

Then, formula (1) which is inserted in formula (2) will get matrix covariance as follows.

$\operatorname{var}\left[\beta_{O L S}-\beta_{G L S}\right]=\operatorname{var}\left(\beta_{O L S}\right)+\operatorname{var}\left(\beta_{G L S}\right)=\operatorname{var}(q)$

Next, Based on Wald criterion, Hausman test will follow chi-square distribution as follows:

$$
m=q \operatorname{var}(q)^{-1} q
$$

Where, $q=\left[\beta_{\mathrm{OLS}}-\beta_{\mathrm{GLS}}\right]$ and $\operatorname{var}\left(\beta_{\mathrm{OLS}}\right)-\operatorname{var}\left(\beta_{\mathrm{GLS}}\right)$

Hausman test follows chi-square distribution with degree of freedom as the number of $\mathrm{k}$. Where, $\mathrm{k}$ is the number of independent variable. If null hypothesis is rejected, it means that the score of Hausman test is higher than its critics score or value and it indicates that the appropriate model is fixed effect. In contrast, if the null hypothesis is accepted, it means that score of
Hausman test is lower than its critics score or value and it indicates that the appropriate model is random effect.

This research used an analysis of regretion of panel data as analysis tool. For more details, it can be seen as follows:

$$
\mathrm{Y}_{\mathrm{it}}=\beta_{0}+\beta_{1} \mathrm{X}_{1 \mathrm{t}}+\beta_{2} \mathrm{X}_{2 \mathrm{t}}+\cdots+\beta_{\mathrm{n}} \mathrm{X}_{\mathrm{it}}+\varepsilon_{\mathrm{it}}
$$

(Gujarati, 2010)

Where :

$\mathrm{Y}_{\text {it }}=$ Dependent variable

$\mathrm{X}_{\mathrm{it}}=$ Independent variable

$\mathrm{i}=$ Cross section

$\mathrm{t}=$ Time series

$\varepsilon=$ Error term

Based on the regretion model of panel data which is elaborated by Gujarati (2010), the researche or writer replicates its model. The model of panel data regretion as follows.

$\operatorname{LOG}\left(\mathrm{PDRB}_{\mathrm{it}}\right)=\beta_{0}+\beta_{1} \mathrm{JALAN}_{1 \mathrm{t}}+\beta_{2}{ }_{2}$ PELABUHAN $2 \mathrm{tt}+\beta_{3}$ $\mathrm{AIR}_{3 \mathrm{t}}+\beta_{4}$ LISTRIK $_{4 \mathrm{t}}+\varepsilon_{\text {it }} \ldots$

Where :

LOG $\left(\mathrm{PDRB}_{\mathrm{it}}\right)=$ Economic growth

JALAN $_{1 \mathrm{t}}=$ Road infrastructure

PELABUHAN $_{2 \mathrm{t}}=$ Harbor infrastructure

$\mathrm{AIR}_{3 \mathrm{t}}=$ Water infrastructure

LISTRIK $_{4 \mathrm{t}}=$ Electricity infrastructure i

$\mathrm{t}$

$\varepsilon_{\text {it }}$

$=$ Cross section

$=$ Time series

$=$ Error term

\section{RESULTS AND DISCUSSION}

Based on the results test between common effect and fixed effect, it was found that fixed effect is appropriate method, it can be proved by looking at the F test result, where F-statistic score is 41,278740 with the score of F-tablein d.f $(11,44) \alpha=5 \%$ is 5.32 , so the score of F-statistic is higher than F-table. Therefore, the suitable model of panel data is fixed effect.

Thus, fixed model effect with panel data technique can be used to know the effect of road, harbor, electricity and waterinfrastructures on economic growth in Southeast Sulawesi. The estimation result by using fixed effect model can be found the regretion of panel data in Table 1 .

Tabel 1 showed that road, harbor, water and electricity infrastructures significantly affected on economic growth at regency or city in Southeast Sulawesi. It can be proved by looking at the probability score or F score is 0,00000 which lower than $\alpha$ five per cent maupun $\alpha$ one per cent.

The contribution of infrastructures (road, harbor, water and electricity) toward the economic growth can be seen from $\mathrm{R}^{2}$-adjusted. 
Based on estimation result, $\mathrm{R}^{2}$-adjusted is 0.970767 . It indicated that 97,07 per cent the economic growth of Regency or city in Southeast Sulawesi was decided by the ratio of infrastructures (road, harbor, water and electricity). In other words, the effect of infrastructures (road, harbor, water and electricity) on economic growth of Regency or city in Southeast Sulawesi was 97,07 per cent. And the rest was 2,93 per cent decided by other variables.

Partially, independent variables (harbor and electricity infrastructures) significantly influenced on economic growth of Regency or city in Southeast Sulawesi. Economically, this thing is possible because Indonesia is dominated by sea and Indonesia has many islands, thus, harbor infrastructure has an important role as national connectivity door for national and international trade. Besides, the economic growth in Southeast Sulawesi is more dominated by primer sector, so harbor infrastructure has essential role. However, other two independent variables namely road and water infrastructures did not significantly influenced on the economic growth of Southeast Sulawesi.

\section{CONCLUSION}

Based on the research results and discussion, it can be concluded that infrastructures (road, harbor, water and electricity) were simultaniously and significantly affected on the economic growth of Southeast Sulawesi. However, partially, only harbor and electricity significantly influenced on the economic growth of SoutheastSulawesi because water and road infrastructures had still obstacles. For example, the distribution of clean water to consumen is not optimum. Then, the condition of the road in regency or city does not have good quality until now.

\section{REFERENCE}

Agus Widarjono. 2013. Ekonometrika Pengantar dan Aplikasinya.Edisi Keempat, Yogyakarta, UPP STIM YKPN.

Badan Pusat Statistik. 2010-2014. Sulawesi Tenggara dalam angka 2010-2014.Sultra: Badan Pusat Statistik.

Calderón, C. E. Moral-Benito dan L. Servén. 2011. Is Infrastructure Capital Productive? ADynamic Heteregenous Approach, World Bank Policy Research Working Paper 5682

Demurger, S., 2001. Infrastructure Development and
Economic Growth: An Explanation for Regional Disparities in China? Journal of Comparative Economics 29, 95-117.

Ghosh, B. dan P. De. 2005. Investigating The Linkage Between Infrastructure and Regional Development in India: Era Of Planning To Globalization. Journal Of Asian Economies. Vol. 15, No. 6, PP- 1023- 1050.

Gujarati, Damodar N. 2010. Dasar-Dasar ekonometrika Buku 1, (edisi ke-5). Jakarta: Salemba Empat.

$\mathrm{Vu}$ Le, M., \& Suruga, T. 2005. Foreign Direct Investment, Public Expenditure and Economic Growth: The Empirical Evidence for the Period 1970-2001. Applied Economic Letters.

Munnell, A.H.1990. How does Public Infrastructure Affect Regional Performance?, New England Economic Review, Sept./Oct., 11-32. of Economics, University of Western Australia.

Prasetyo, R.B., 2008. Ketimpangan dan Pengaruh Infrastruktur terhadap Pembangunan Ekonomi Kawasan Barat Indonesia (KBI). Departemen Ilmu Ekonomi, Fakultas Ekonomi dan Manajemen, Institut Pertanian Bogor.

Prasetyo, R.B., dan M. Firdaus, 2009. Pengaruh Infrastruktur pada Pertumbuhan Ekonomi Wilayah Indonesia. Jurnal Ekonomi dan Kebijakan Pembangunan, 2(2): 222-236.

Semmler, Willi \& Greiner, Alfred \& Diallo, Bobo \& Rezai, Armon \& Rajaram, Anand,. 2007. "Fiscal policy, public expenditure composition, and growth theory and empirics," Policy Research Working Paper Series 4405, The World Bank.

Sibarani, M.H.M., 2002. Kontribusi Infrastruktur terhadap Pertumbuhan Ekonomi Indonesia. Tesis Magister Sains. Program Pascasarjana, Universitas Indonesia, Jakarta.

Stiglizt, E. Joseph. 2000. Economics Of The Public Sector. 3 Edition. New York: narton.

Todaro,P Micahel, Smith C Stephen. 2007. Pembangunan Ekonomi di Negara Dunia Ketiga (Edisi kedembilan) Jilid1. (Haris Munanda,Puji A.L). Jakarta: Erlangga.

World Bank, 1994. World Development Report: Infrastructure for Development. Oxford University Press, New York.

Wu, Y., 1998. Income Disparity and Convergence in China's Regional Economies. Department

Yanuar, R., 2006. Kaitan Pembangunan Infrastruktur dan Pertumbuhan Output serta Dampaknya terhadap Kesenjangan di Indonesia. Tesis Magister Sains. Program Pascasarjana IPB, Bogor. 
Tabel 1. Research result with Data Panel 2009 - 2015

\begin{tabular}{|c|c|c|c|}
\hline \multicolumn{4}{|c|}{ Fixed Effects } \\
\hline \multicolumn{4}{|c|}{ (Cross) } \\
\hline BAUBAU_C & & \multicolumn{2}{|l|}{-0.1803420} \\
\hline KONSEL_C & & \multicolumn{2}{|l|}{0.3758120} \\
\hline WAKATOBI_C & & \multicolumn{2}{|c|}{-0.8249380} \\
\hline KOLAKA_C & & \multicolumn{2}{|l|}{1.0503040} \\
\hline KOLUT_C & & \multicolumn{2}{|l|}{0.3038020} \\
\hline KONAWE_C & & \multicolumn{2}{|l|}{0.2230470} \\
\hline MUNA_C & & \multicolumn{2}{|l|}{0.3872010} \\
\hline BOMBANA_C & & \multicolumn{2}{|l|}{-0.3808600} \\
\hline KENDARI_C & & \multicolumn{2}{|l|}{0.3512910} \\
\hline BUTON_C & & \multicolumn{2}{|c|}{-0.0250370} \\
\hline BUTUR_C & & \multicolumn{2}{|l|}{-0.4692650} \\
\hline KONUT_C & & \multicolumn{2}{|l|}{-0.8110160} \\
\hline R-squared & 0.9782 & Mean dependent var & 15.23854 \\
\hline Adjusted R-squared & 0.9708 & S.D. dependent var & 4.74865 \\
\hline S.E. of Regression & 0.1181 & Sum squared resid & 0.61365 \\
\hline F-statistic & 131.6159 & Durbin-Watson stat & 0.83492 \\
\hline \multicolumn{4}{|l|}{ Prob (F-statistic) } \\
\hline \multicolumn{4}{|c|}{ Unweighted Statistics } \\
\hline R-squared & 0.977643 & Mean dependent var & 13.60499 \\
\hline Sum squared resid & 0.649037 & Durbin-Watson stat & 0.77713 \\
\hline
\end{tabular}

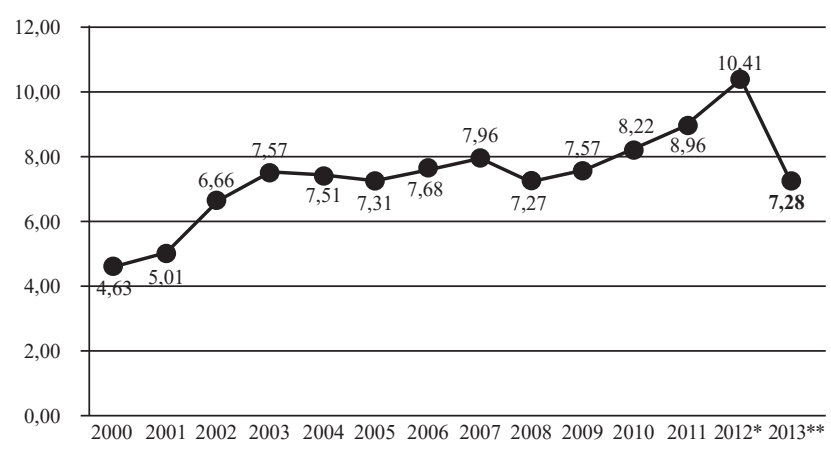

Figure 1. The Economic Growth of Southeast Sulawesi

Source : Output Eviews 7.0 